\title{
Quality control and TLC profile data on selected plant species commonly found in the Brazilian market
}

\author{
Renato Braz, Luciana G. Wolf, Gisely C. Lopes, João C. P. de \\ Mello*
}

Programa de Pós-graduação em Ciências Farmacêuticas, Universidade Estadual de Maringá, Brazil.

\begin{abstract}
The use of thin-layer chromatography (TLC) is a commonplace practice and can be of significant help to different laboratories with quality control, especially those that work with plant extracts and phytotherapeutics. This study evaluated ten species of plants (Schinus terebinthifolius, Arctium lappa, Trichilia catigua, Camellia sinensis, Mikania glomerata, Croton moritibensis, Achyrocline satureioides, Heteropterys aphrodisiaca, Plantago major, Arctostaphylos uva-ursi) that are commonly sold by compounding pharmacies, using TLC with reference substances and pharmacopoeic physical and chemical tests (loss on drying, level of extractives, and total ash content). The results showed that the ten species showed losses on drying consonant with the literature. The level of extractives for two species and total ash for five species were also consonant with the literature, and those of the other species were established in this study. The semipurified extracts of the ten species were assayed by TLC, and the analysis with the use of reference substances proved to be effective, in addition to being practical, simple, versatile, and economically viable.
\end{abstract}

Revista Brasileira de Farmacognosia Brazilian Journal of Pharmacognosy 22(5): 1111-1118, Sep./Oct. 2012

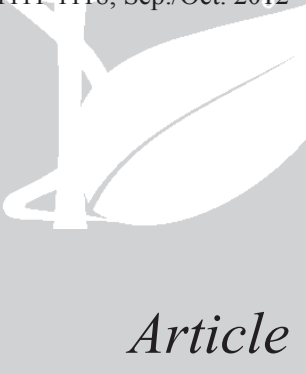

Received 26 May 2011

Accepted 3 Aug 2011

Available online 16 Nov 2011

Keywords:

plant drugs

physico-chemical analysis quality control

thin-layer chromatography

ISSN 0102-695X http://dx.doi.org/10.1590/S0102 $695 \times 2011005000204$

\section{Introduction}

Medicinal plants, herbal drugs, and individual natural products comprise a market worth billions of dollars, in both developed and developing countries. The field of phytotherapy is growing remarkably, with a present worldwide market value of approximately 22 billion dollars, of which Brazil accounts for about $23 \%$ (Calixto, 2000). It is estimated that $82 \%$ of the Brazilian population uses herb-based products, and the herbal market sector includes about 200 companies with a total output of one billion Brazilian reals and more than a hundred thousand employees within the country (Abifito, 2006).

Phytotherapeutics are marketed through establishments such as the drugstores, where the plant preparations are sold as pharmaceutical specialties and are industrially produced; and the compounding pharmacies, where the medicines are compounded from plant extracts or sold as plant drugs in natura. Access to phytotherapeutics made by a compounding pharmacy is guaranteed by the provisions of Law No. 5991/1973 (Brasil, 1973) and Resolution No. 10/2010 (Anvisa, 2010). The increasing public demand for natural medicines has resulted in increased commercial activity and production of these medicines. This has led to growing concern in regard to ensuring the quality and safety of medicinal plants and herbal drugs.

Several national and international agencies have prioritized the issue of ensuring the quality of plant drugs. The effort of the World Health Organization is outstanding: over 20 years ago, it first published quality-control methods for medicinal plant materials, which have been regularly updated. These published methods were followed by a series of monographs on globally important medicinal plants (WHO, 2000). However, for medicinal plants that do not appear in these official codes, studies must be conducted to establish parameters to ensure their quality, according to technical and scientific principles (Farias, 2004).

In order to effectively coordinate the quality of raw materials, processing of materials, and the final products, it has become essential to develop reliable, specific, and sensitive quality-control methods using a combination of classical and modern instrumental methods of analysis. In this context, thin-layer chromatography (TLC), also called planar chromatography, is a widely accepted and extensively used separation technique that is over 65 years old (Poole, 1999). The technique is simple, cost-effective, versatile, and usable in all laboratories worldwide. It can be easily adapted to any given situation of qualitative 
or quantitative separation (Ferenczi-Fodor et al., 2006). The uses of TLC in quality control of plant materials include fingerprint profiling for the assessment of chemical constituents of an extract, and quantitative analysis of markers in plant drugs (Mohammad et al., 2010).

Such a chromatographic profile should feature the fundamental attributes of "integrity" and "fuzziness" so as to chemically represent the herbal medicines investigated. This suggests that the chromatographic fingerprint can also successfully demonstrate both "differences" and "uniformity" between various samples, and the authentication and identification of herbal medicines can be accurately conducted even if the number and/or concentrations of chemically characteristic constituents vary in different samples (Liang et al., 2004). Therefore, the chromatographic fingerprint should be considered in evaluating the overall quality of herbal medicines, considering the multiple constituents that are present in medicinal plants and herbal drugs. Thus, TLC remains the method of choice to obtain the first characteristic fingerprint profile of a medicinal plant and herbal drug.

Compounding pharmacies encounter considerable difficulty in establishing parameters for the analysis of plant and herbal drugs. TLC can and should be employed to aid these compounding pharmacies in controlling the quality of their plant and herbal drugs, so as to guarantee the chemical quality of the extracts. Therefore, the present contribution lists several plant species that are commonly used in phytotherapy, and provides data on their physical, chemical, and chromatographic attributes, in order to facilitate quality control.

\section{Material and Methods}

\section{Plant material}

The plants were selected according to surveys carried out in compounding pharmacies in the city of Maringá, state of Paraná, Brazil, and are listed in Table 1. The species were identified by Prof. Dr. Cassia Mônica Sakuragui. Voucher specimens are deposited in the herbarium of the Department of Biology of the State University of Maringá.

\section{Reagents, standard solutions and materials}

All solvents and reagents used were analytical grade from Synth, and diphenylboric acid 2-aminoethyl ester from Sigma. The reagents used were: ferric chloride at $1 \%$ in methanol, vanillin perchloric (solution A: vanillin at $1 \%$ in ethanol, and solution B: perchloric acid at $3 \%$ in water); natural reagent (diphenylboric acid 2-amino-ethyl ester in methanol at $1 \%$ and then spraying polyethyleneglycol 400 at $5 \%$ in ethanol); potassium hydroxide at $10 \%$ in water; anisaldehyde sulfuric (anisaldehyde $1 \mathrm{~mL}$, sulfuric acid $2 \mathrm{~mL}$, and completed with acetic acid to $100 \mathrm{~mL}$ ). Deionized water was prepared with a Millipore Milli-Q Plus system (Millipore, Bedford, MA, USA). Hydroquinone, epicatechin, catechin, caffeic acid, chlorogenic acid, gallic acid, o-coumaric acid, quercetin, coumarin, lupeol, and rutin (Sigma, USA), isoastilbin and cinchonain $\mathrm{Ib}$ (isolated and certified by spectroscopic methods at the Pharmaceutical Biology Laboratory of the Universidade Estadual de Maringá; Marques et al., 2007; Resende et al., 2011), and epicatechin-3-Ogallate (kindly provided by Dr. Frank Petereit, Institute for Pharmaceutical Biology and Phytochemistry of the Universität Münster, Germany; Danne et al., 1994) of the highest grade (purity $>99.0 \%$ ) were used as external standards.

Stock solutions $(1 \mathrm{mg} / \mathrm{mL})$ of the standards were prepared on the day of analysis in methanol, immediately before use.

Table 1. List of plant species assayed, with their Brazilian common names and botanical identification.

\begin{tabular}{|c|c|c|c|}
\hline $\begin{array}{l}\text { Common name } \\
\text { Species name }\end{array}$ & Family & Voucher Code & Part \\
\hline $\begin{array}{l}\text { Aroeira } \\
\text { Schinus terebinthifolius } \\
\text { Raddi }\end{array}$ & Anacardiaceae & HUEM 12677 & Bark \\
\hline $\begin{array}{l}\text { Bardana } \\
\text { Arctium lappa } \mathrm{L} .\end{array}$ & Asteraceae & RFA 35.777 & Leaves \\
\hline $\begin{array}{l}\text { Catuaba } \\
\text { Trichilia catigua A. Juss. }\end{array}$ & Meliaceae & MBM 65901 & Bark \\
\hline $\begin{array}{l}\text { Chá-verde } \\
\text { Camellia sinensis (L.) } \\
\text { Kuntze }\end{array}$ & Theaceae & $\begin{array}{l}\text { Opção Fênix, } \\
\text { Lot: } 065 \mathrm{~F} / 05\end{array}$ & Leaves \\
\hline $\begin{array}{l}\text { Guaco } \\
\text { Mikania glomerata Spreng. }\end{array}$ & Asteraceae & HUEM 8420 & Leaves \\
\hline $\begin{array}{l}\text { Marapuama } \\
\text { Croton moritibensis Baill. }\end{array}$ & Euphorbiaceae & $\begin{array}{c}\text { Ambrosifarma, } \\
\text { Lot: } 2261998\end{array}$ & Bark \\
\hline $\begin{array}{l}\text { Marcela } \\
\text { Achyrocline satureioides } \\
\text { (Lam.) DC. }\end{array}$ & Asteraceae & HUEM 5270 & Inflorescences \\
\hline $\begin{array}{l}\text { Nó-de-cachorro } \\
\text { Heteropterys aphrodisiaca } \\
\text { A. Juss. }\end{array}$ & Malpighiaceae & $\begin{array}{l}\text { HUFMT } \\
22.181\end{array}$ & Roots \\
\hline $\begin{array}{l}\text { Tansagem } \\
\text { Plantago major } \mathrm{L} \text {. }\end{array}$ & Plantaginaceae & HUEM 8427 & Leaves \\
\hline $\begin{array}{l}\text { Uva-ursi } \\
\text { Arctostaphylos uva-ursi } \\
\text { (L.) Spreng. }\end{array}$ & Ericaceae & $\begin{array}{c}\text { Natural } \\
\text { Pharma, Lot: } \\
\text { 1611R/015 }\end{array}$ & Leaves \\
\hline
\end{tabular}

\section{Instrumentation}

Tigre ASN5 hammer mill; Ika ${ }^{\circledR}$ MS1 Eppendorf shaker; Fisatom ${ }^{\circledR} 712$ mechanical shaker; AND ${ }^{\circledR}$ HR-200 analytical balance; Gahaka ${ }^{\circledR}$ BG2000 semi-analytical balance; Water bath; Vacuubrand ${ }^{\circledR}$ MZ 2C vacuum pump; Ultraviolet chamber with $254 \mathrm{~nm}$ and $365 \mathrm{~nm}$ 
lamps; Fanen ${ }^{\circledR} 315 \mathrm{SE}$ hot air oven; Christ ${ }^{\circledR}$ Alpha 1-4 LD lyophilizer; and Büchi ${ }^{\circledR}$ B-480 rotary evaporator.

\section{Preparation of plant extracts}

The plant material was used with no separation of particle sizes. For all plant drugs, extracts were prepared at room temperature in a mechanical shaker with helices at $500 \mathrm{rpm}$, in the proportion of $10 \%$ $(\mathrm{w} / \mathrm{v})$ of the drug in $50 \%$ ethanol $(\mathrm{v} / \mathrm{v})$. The extractive solutions were filtered and used in the preliminary analysis. For chromatographic analysis, the extracts obtained were concentrated in a rotary evaporator under reduced pressure $\left(t<40{ }^{\circ} \mathrm{C}\right)$. After elimination of the organic phase, the extracts (CE) were freeze-dried and stored in amber bottles protected from light, heat, and moisture.

Preparation of final solutions for chromatographic analysis

The amount of CE needed for each plant was established by prior testing. Thus, accurately weighed $200 \mathrm{mg}$ portions of each CE of 'aroeira', 'bardana', 'catuaba', 'chá-verde', 'marapuama', 'nó-de-cachorro', 'tansagem', 'marcela'; $100 \mathrm{mg} \mathrm{CE}$ of 'guaco', and 50 mg CE of 'uva-ursi' were dissolved in $500 \mu \mathrm{L}$ water. All extracts were mixed in a tube shaker, and extracted with $500 \mu \mathrm{L}$ of ethyl acetate (except for $n$-hexane in the case of 'marapuama'; Barbosa et al., 2003) in a microtiter shaker at $1400 \mathrm{rpm}$ (IKA, MS1 Minishaker) for $5 \mathrm{~min}$. Then, the tubes were placed in a refrigerated microcentrifuge (Eppendorf, Centrifuge 5415R), at $4000 \mathrm{x} g$ for $4 \mathrm{~min}$ at $5{ }^{\circ} \mathrm{C}$, for the total separation of the phases. The organic phase was collected for analysis. After evaporation of solvents, and drying under air flow, the residue was reconstituted to $1 \mathrm{~mL}$ with methanol (Test Solution - TS) and applied on chromatography plates (see conditions below) with the aid of volumetric micropipettes, which always dispensed $5 \mu \mathrm{L}$ or a multiple of this volume.

Phytochemical screening and physical and chemical analyses

For identification of flavonoids, coumarins, iridoids, tannins, simple phenolics, methylxanthines, alkaloids and saponins, tests were conducted according to the respective techniques described by Harborne (1998) and the foaming index test for saponins as described by Schenkel et al. (2003). The loss on drying and total ash content were determined according to the Farmacopeia Brasileira (2010). The methodology used to determine the level of extractives was carried out as described by Deutsches (1986). All tests were conducted in triplicate with three replicates.

Chromatographic analysis

This assay was conducted by analytical thinlayer chromatography (ATLC), using aluminum sheets of silica gel $\mathrm{F}_{254}\left(\mathrm{Merck}^{\circledR}\right)$. All chromatograms were developed in a saturated chamber. Mobile phases employed in this study were selected or developed according to the reference substance for each drug, and are listed in Table 2. Aliquots of the standards and TS (Table 2) were spotted onto a plate with volumetric micropipettes, along a virtual line situated $10 \mathrm{~mm}$ from the bottom edge of the plate $(100 \times 50 \mathrm{~mm})$. The spots were applied at $13-\mathrm{mm}$ intervals. During application, care was taken to dry the spots with a stream of cold air so that they never exceeded a diameter of ca. 5 $\mathrm{mm}$. The plate was developed to a distance of $80 \mathrm{~mm}$, at room temperature. After the chromatogram was developed, the plates were dried and the spots were visualized sequentially under UV light at 254 and 365 $\mathrm{nm}$, and then sprayed with specific chromogenic agents according to the chemical substances analyzed (Table 2).

\section{Results and Discussion}

Although the use of herbal drugs is increasing throughout the world, reports on their side effects and instances of adulteration have raised concerns regarding their wide use, and are affecting their marketing (Cianchino et al., 2008). Correct identification and quality assurance of the starting material is an essential prerequisite to ensure reproducible quality of an herbal medicine, which contributes to its safety and efficacy. It is essential to establish a system of standardization for every plant medicine on the market, because of the enormous scope for variation in different batches. Plant material may vary in its chemical content and therefore in its therapeutic effect according to the collection location; the time of year when the material was collected; among different years of collection, even at the same time of year and location; and with differences in environmental factors during the cultivation of the plant (Sahoo et al., 2010). This means that all raw materials should undergo a quality-control test, to ensure the quality of the product.

A general screening was conducted to characterize the chemical composition of the plant drugs under study. The results revealed the presence of secondary metabolites including flavonoids, coumarins, tannins, simple phenolics, methylxanthines, alkaloids, and saponins. No iridoids were detected in any of the extracts. Phytochemicals such as flavonoids, phenolic compounds, and tannins were present in all the crude extracts analyzed, except for the 'marapuama' extract. 
Methylxanthines were present only in 'chá-verde', alkaloids only in 'aroeira' and 'marapuama', saponins only in 'marapuama' and 'nó-de-cachorro', and coumarin only in 'guaco'. From the preliminary results of the chemical analyses, it was possible to determine the chemical marker for each plant drug. These data were corroborated from literature sources (Oliveira et al., 1984 apud Osório \& Martins, 2004; Kawashty et al., 1994; Müller \& Kasper, 1996; Veneziani \& Oliveira, 1999; Pereira et al., 2000; De Souza, 2002; Pizzolatti et al., 2002; Yang \& Lambert, 2003; Araújo-Junior et al., 2004; Polydoro et al., 2004; Chan et al., 2007; Marques et al., 2007; Resende et al., 2011; Manian et al., 2008;
Silva et al., 2010).

Chemotaxonomic markers are sometimes used as indicators of botanical identity or as tools in manufacturing to help ensure the consistency of products. Therefore, the selection of chemical markers is crucial for the quality control of plant drugs, including authentication of genuine species, harvesting the best-quality raw materials, evaluation of postharvest handling, and assessment of intermediates and finished products (Ahmad et al., 2010). Table 3 shows the Rf values of the standards used in the development of TLC, and their respective colors.

Thin-layer chromatography (TLC) is a popular

Table 2. Chemical standards, eluent systems and visualizing agents used in the TLC.

\begin{tabular}{|c|c|c|c|}
\hline Plant drugs Standards & Aliquots $(\mu \mathrm{L})$ & Eluent systems (v/v) & Chromogenic agent \\
\hline $\begin{array}{l}\text { Aroeira } \\
\text { Gallic acid } \\
\text { Catechin }\end{array}$ & $\begin{array}{c}25.0 \\
5.0 \\
25.0\end{array}$ & $\begin{array}{l}\text { 1. Toluene: ethyl acetate: methanol: formic acid }(75: 25: 10: 6) \\
\text { 2. Ethyl acetate: toluene: formic acid: water }(80: 10: 5: 5)\end{array}$ & $\begin{array}{l}\text { A. Ferric chloride } 1 \% \text { in methanol } \\
\text { B. Vanillin perchloric }+105^{\circ} \mathrm{C} / 5 \mathrm{~min}\end{array}$ \\
\hline $\begin{array}{l}\text { Bardana } \\
\text { Chlorogenic acid } \\
\text { Rutin }\end{array}$ & $\begin{array}{c}25.0 \\
15.0 \\
5.0\end{array}$ & $\begin{array}{l}\text { 3. Ethyl acetate: water: formic acid: acetic acid } \\
\qquad(100: 27: 11: 11)\end{array}$ & C. NR + PEG $400+$ UV 365 nm \\
\hline $\begin{array}{l}\text { Catuaba } \\
\text { Cinchonain Ib }\end{array}$ & $\begin{array}{c}15.0 \\
5.0\end{array}$ & 4. Chloroform: acetic acid: methanol: water $(32: 16: 6: 4)$ & B. Vanillin perchloric $+105^{\circ} \mathrm{C} / 5 \mathrm{~min}$ \\
\hline $\begin{array}{l}\text { Chá-verde } \\
\text { Epicatechin } \\
\text { Epicatechin-3-O-gallate }\end{array}$ & $\begin{array}{c}5.0 \\
10.0 \\
5.0\end{array}$ & 2. Ethyl acetate: toluene: formic acid: water $(80: 10: 5: 5)$ & B. Vanillin perchloric $+105^{\circ} \mathrm{C} / 5 \mathrm{~min}$ \\
\hline $\begin{array}{l}\text { Guaco } \\
o \text {-Coumaric acid } \\
\text { Coumarin }\end{array}$ & $\begin{array}{c}15.0 \\
5.0 \\
5.0\end{array}$ & 5. Toluene: dichloromethane: acetone $(45: 25: 30)$ & $\begin{array}{l}\text { D. Potassium hydroxide } 10 \%+\mathrm{UV} \\
\qquad 365 \mathrm{~nm}\end{array}$ \\
\hline $\begin{array}{l}\text { Marapuama } \\
\text { Lupeol }\end{array}$ & $\begin{array}{l}10.0 \\
10.0\end{array}$ & 6. Toluene: dichloromethane: acetone $(45: 30: 25)$ & E. Anisaldehyde $+105^{\circ} \mathrm{C} / 5 \mathrm{~min}$ \\
\hline $\begin{array}{l}\text { Marcela } \\
\text { Caffeic acid } \\
\text { Quercetin }\end{array}$ & $\begin{array}{c}10.0 \\
15.0 \\
5.0\end{array}$ & 1. Toluene: ethyl acetate: methanol: formic acid $(75: 25: 10: 6)$ & C. NR + PEG $400+$ UV 365 nm \\
\hline $\begin{array}{l}\text { Nó-de-cachorro } \\
\text { Isoastilbin }\end{array}$ & $\begin{array}{c}10.0 \\
5.0\end{array}$ & 7. Ethyl acetate: formic acid: water $(90: 5: 5)$ & A. Ferric chloride $1 \%$ in methanol \\
\hline $\begin{array}{l}\text { Tansagem } \\
\text { Caffeic acid } \\
\text { Chlorogenic acid }\end{array}$ & $\begin{array}{l}35.0 \\
15.0 \\
15.0\end{array}$ & 1. Toluene: ethyl acetate: methanol: formic acid $(75: 25: 10: 6)$ & C. NR + PEG $400+$ UV 365 nm \\
\hline $\begin{array}{l}\text { Uva-ursi } \\
\text { Gallic acid } \\
\text { Hydroquinone }\end{array}$ & $\begin{array}{c}15.0 \\
5.0 \\
5.0\end{array}$ & 1. Toluene: ethyl acetate: methanol: formic acid $(75: 25: 10: 6)$ & A. Ferric chloride $1 \%$ in methanol \\
\hline
\end{tabular}

Table 3. $\mathrm{R}_{\mathrm{f}}$ values of the standards used in TLC and their respective colors.

\begin{tabular}{|c|c|c|c|}
\hline Standard & Plant drugs & Color & $\mathrm{R}_{\mathrm{f}}$ \\
\hline Caffeic acid & Marcela and Tansagem & Blue & 0.35 \\
\hline Chlorogenic acid & Bardana and Tansagem & Blue & 0.58 \\
\hline Gallic acid & Aroeira and Uva-ursi & Brownish-blue & 0.20 \\
\hline$o$-Coumaric acid & Guaco & Light blue & 0.39 \\
\hline Catechin & Aroeira & Orange & 0.81 \\
\hline Cinchonain Ib & Catuaba & Yellow & 0.58 \\
\hline Coumarin & Guaco & Light blue & 0.79 \\
\hline Epicatechin & Chá-verde & Red or orange & 0.80 \\
\hline Epicatechin-3-O-gallate & Chá-verde & Red or orange & 0.66 \\
\hline
\end{tabular}




\begin{tabular}{lccc}
\hline Hydroquinone & Uva-ursi & Brown & 0.49 \\
Isoastilbin & Nó-de-cachorro & Brown & 0.73 \\
Lupeol & Marapuama & Violet & 0.76 \\
Quercetin & Marcela & Orange & 0.40 \\
Rutin & Bardana & Orange & 0.67 \\
\hline
\end{tabular}

Table 4. Results of chromatographic analysis, extracts, standards, eluent systems, and chromogenic agents as listed in Tables 2 and 3.
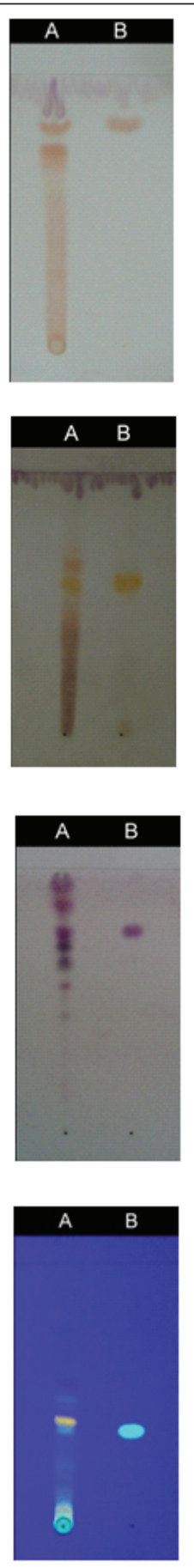

(A) extract of 'aroeira'

(B) catechin $\left(\mathrm{R}_{\mathrm{f}}=0.81\right)$

Eluent system: 2

Chromogenic Agent: B

(A) extract of 'catuaba' (B) cinchonain $\mathrm{Ib}$ $\left(\mathrm{R}_{\mathrm{f}}=0.58\right)$

Eluent system: 4

Chromogenic Agent: B

(A) extract of 'marapuama'

(B) lupeol $\left(\mathrm{R}_{\mathrm{f}}=0.76\right.$

Eluent system: 6

Chromogenic Agent: E

(A) extract of

'tansagem'

(B) caffeic acid

$\left(\mathrm{R}_{\mathrm{f}}=0.35\right)$

Eluent system: 1

Chromogenic Agent: C

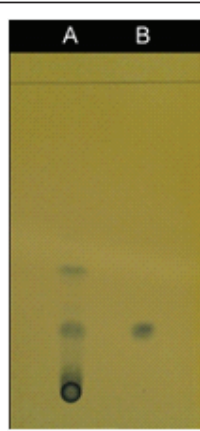

(A) extract of 'aroeira'

(B) gallic acid $\left(\mathrm{R}_{\mathrm{f}}=0.20\right)$

Eluent system: 1

Chromogenic Agent: A

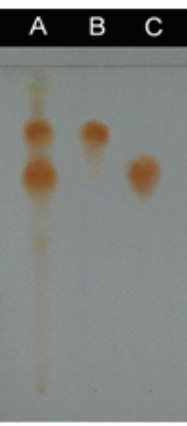

(A) extract of 'chá verde'

(B) epicatechin $\left(\mathrm{R}_{\mathrm{f}}=0.80\right)$

(C) epicatechin-3-O-

gallate $\left(\mathrm{R}_{\mathrm{f}}=0.66\right)$

Eluent system: 2

Chromogenic Agent: B

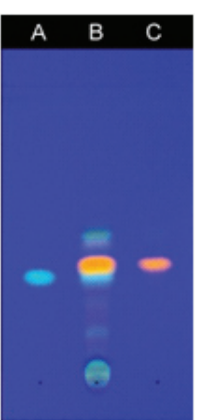

(A) caffeic acid

$\left(\mathrm{R}_{\mathrm{f}}=0.35\right)$

(B) extract of 'marcela'

(C) quercetin $\left(\mathrm{R}_{\mathrm{f}}=0.40\right.$

Eluent system: 1

Chromogenic Agent: C

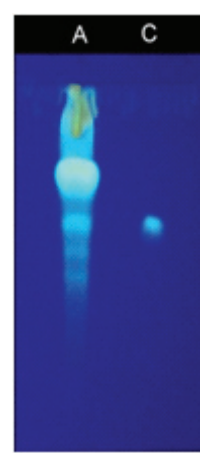

(A) extract of 'tansagem'

(C) chlorogenic acid

$\left(\mathrm{R}_{\mathrm{f}}=0.58\right)$

Eluent system: 1

Chromogenic Agent: C

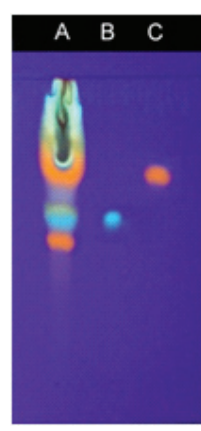

(A) extract of 'bardana'

(B) chlorogenic acid

$\left(\mathrm{R}_{\mathrm{f}}=0.58\right)$

(C) rutin $\left(\mathrm{R}_{\mathrm{f}}=0.67\right)$

Eluent system: 3

Chromogenic Agent: C

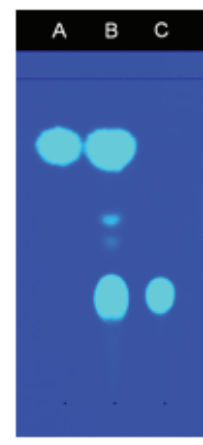

(A) coumarin $\left(\mathrm{R}_{\mathrm{f}}=0.79\right)$

(B) extract of 'guaco'

(C) $o$-coumaric acid

$\left(\mathrm{R}_{\mathrm{f}}=0.39\right)$

Eluent system: 5

Chromogenic Agent: D

A B

(A) extract of ' $n o ́-d e-$ cachorro'

(B) isoastilbin $\left(\mathrm{R}_{\mathrm{f}}=0.73\right)$

Eluent system: 7

Chromogenic Agent: C

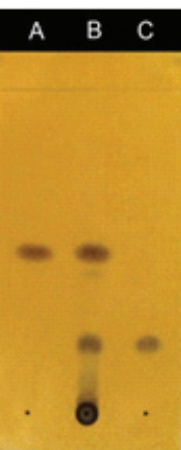

(A) hydroquinone $\left(\mathrm{R}_{\mathrm{f}}=0.49\right)$

(B) extract of 'uva ursi'

(C) gallic acid $\left(\mathrm{R}_{\mathrm{f}}=0.20\right)$

Eluent system: 1

Chromogenic Agent: A 
method to analyze plant drugs (Pittet \& Royer, 2002; Głowniak et al., 2005; Zhang et al., 2008; Barbosa et al., 2009), and has been used for a wide variety of applications. TLC is an important tool, not only for the quality control of medicinal plants, but also for the analysis of herbal drugs (Durón et al., 2009). In several pharmacopoeias, a great variety of plants are identified by use of TLC methods (Farmacopeia Portuguesa, 2002; Farmacopeia Espanhola, 2005; Farmacopeia Brasileira, 2010). TLC has the advantages of low cost, ease of maintenance, and good selectivity of detection. In addition, TLC can analyze several parallel samples in a single run. It also facilitates repeated detection (scanning) of the chromatogram with the same or different parameters. Therefore, the simultaneous assay of several components in a multicomponent formulation is possible. TLC was chosen because this separation system enables simultaneous evaluation of standards and samples, thus matching the working conditions and environment for both, and reducing systematic errors (Kaiser, 2005). The appearance of compounds in common and different bands can be useful for identification and authentication of plant drugs. The TLC profiles of the plant drugs studied are shown in Table 4.

All identifications in the TLC are based on comparison of the migration distances ( $\mathrm{R}_{\mathrm{f}}$ values), and of the color of the spots between the sample and a standard when the TLC plate is sprayed with a specific chromogenic reagent. The quality of the analysis depends on the correct positioning of the sample and on the reference substances used in the TLC. Accordingly, we opted to apply the samples in spots, to improve the visual impression of the chromatogram. Another fundamental parameter in evaluating samples in TLC is the volume of the sample and reference substances applied, which must be well defined and reproducible because the quality of separation depends on the size, shape, and homogeneity of the application zones (Reich \& Blatter, 2003).

In all cases, the criterion for acceptance of the TLC procedure was adequate detection of the specific marker, with respect to the color and relative position of the band. The band of the specific marker should always be present in the chromatogram obtained from the samples.

The physical and chemical tests carried out in this study, including loss on drying, content in extracts, and total ash content, showed that the herbal drugs analyzed were within the technical specifications proposed by the appropriate literature, when available. Data are shown in Table 5.

In conclusion, based on the results obtained, we can suggest that the tests performed can aid in the quality control of the herbal drugs analyzed, contributing significantly to the quality-control protocol. These tests are also useful to indicate the existence of fraud, a common occurrence in the medicinal-plants market, which may consist of adulteration or even falsification of raw plant materials (Liang et al., 2004; Barbosa et al., 2009). However, it should also be borne in mind that TLC plates from different manufacturers, with different thicknesses and particle sizes, can also give variable results for a particular assay method.

Table 5. Results from physico-chemical analyses.

\begin{tabular}{|c|c|c|c|c|c|c|}
\hline \multirow{3}{*}{$\begin{array}{l}\text { Common name } \\
\text { Species name }\end{array}$} & \multicolumn{6}{|c|}{ Physico-chemical analyses } \\
\hline & \multicolumn{2}{|c|}{ Loss on drying } & \multicolumn{2}{|c|}{ Level of extractives } & \multicolumn{2}{|c|}{ Total ash } \\
\hline & {$[\bar{x} \pm d p(\mathrm{CV} \%)]$} & Reference & {$[\bar{x} \pm d p(\mathrm{CV} \%)]$} & Reference & {$[\bar{x} \pm d p(\mathrm{CV} \%)]$} & Reference \\
\hline $\begin{array}{l}\text { Aroeira } \\
\text { Schinus terebinthifolius }\end{array}$ & $12.93 \pm 0.48(3.55)$ & $8-14 \%{ }^{1}$ & $25.86 \pm 0.24(0.93)$ & - & $4.21 \pm 0.11(2.52)$ & - \\
\hline $\begin{array}{l}\text { Bardana } \\
\text { Arctium lappa }\end{array}$ & $11.45 \pm 0.37(3.27)$ & $8-14 \%{ }^{1}$ & $33.94 \pm 1.32(3.89)$ & Min. $20 \% 0^{3}$ & $3.42 \pm 0.10(2.95)$ & Max. $15 \%{ }^{3}$ \\
\hline $\begin{array}{l}\text { Catuaba } \\
\text { Trichilia catigua }\end{array}$ & $10.42 \pm 0.08(0.77)$ & $8-14 \%{ }^{1}$ & $24.62 \pm 0.74(3.00)$ & - & $6.90 \pm 0.06(0.87)$ & - \\
\hline $\begin{array}{l}\text { Chá-verde } \\
\text { Camellia sinensis }\end{array}$ & $8.21 \pm 0.21(2.50)$ & $8-14 \%^{1}$ & $42.39 \pm 0.75(1.79)$ & - & $3.12 \pm 0.14(4.40)$ & - \\
\hline $\begin{array}{l}\text { Guaco } \\
\text { Mikania glomerata }\end{array}$ & $8.74 \pm 0.20(2.29)$ & $10 \%{ }^{2}$ & $24.43 \pm 0.60(2.46)$ & - & $5.40 \pm 0.11(2.04)$ & $15 \%{ }^{2}$ \\
\hline $\begin{array}{l}\text { Marapuama } \\
\text { Croton moritibensis }\end{array}$ & $9.13 \pm 0.07(0.77)$ & $14 \%$ & $2.29 \pm 0.08(3.50)$ & - & $2.09 \pm 0.07(3.35)$ & - \\
\hline $\begin{array}{l}\text { Marcela } \\
\text { Achyrocline satureioides }\end{array}$ & $6.29 \pm 0.16(2.54)$ & $10 \%{ }^{4}$ & $14.16 \pm 0.25(1.75)$ & - & $3.17 \pm 0.08(2.52)$ & $8 \%{ }^{4}$ \\
\hline $\begin{array}{l}\text { Nó-de-cachorro } \\
\text { Heteropterys aphrodisiaca }\end{array}$ & $11.95 \pm 0.35(2.90)$ & $7.5-15.8 \%{ }^{5}$ & $33.41 \pm 1.05(3.14)$ & $31-50 \% 0^{5}$ & $4.73 \pm 0.07(1.41)$ & $3.5-5.3 \% 5$ \\
\hline $\begin{array}{l}\text { Tansagem } \\
\text { Plantago major }\end{array}$ & $9.87 \pm 0.19(1.93)$ & $8-14 \%{ }^{1}$ & $42.70 \pm 0.77(1.80)$ & - & $13.70 \pm 0.37(2.70)$ & - \\
\hline $\begin{array}{l}\text { Uva-ursi } \\
\text { Arctostaphylos uva-ursi }\end{array}$ & $8.52 \pm 0.24(2.82)$ & $10 \%{ }^{4}$ & $38.35 \pm 0.78(2.03)$ & - & $3.23 \pm 0.09(2.78)$ & $5 \%{ }^{4}$ \\
\hline
\end{tabular}

${ }^{1}$ Bacchi (1996); ${ }^{2}$ Farmacopeia Brasileira (2002); ${ }^{3}$ British Herbal Pharmacopoeia (1996); ${ }^{4}$ Farmacopoeia Portuguesa (2002); ${ }^{5}$ Marques et al. (2007). 


\section{Acknowledgements}

The authors thank the Brazilian funding agencies CNPq, Fundação Araucária, INCT_if, and CAPES. Our gratitude to Dr. Janet W. Reid for revising the English text. The valuable observations of anonymous reviewers contributed significantly to improvements in the manuscript.

\section{References}

Abifito 2006. Uma legislação justa para os produtos de origem natural. <http://www.abifito.com.br/introducao.asp>, accessed on: 9 Jul 2006.

Agência Nacional de Vigilância Sanitária 2010, Resolução Específica (RE) 10 de 10 de março de 2010, Dispõe sobre a notificação de drogas vegetais junto à Agência Nacional de Vigilância Sanitária (ANVISA) e dá outras providências, Diário Oficial da União.

Ahmad M, Khan MA, Zafar M, Arshad M, Sultana S, Abbasi BH, Ud-Din S 2010. Use of chemotaxonomic markers for misidentified medicinal plants used in traditional medicines. J Med Plants Res 4: 1244-1252.

Araújo-Júnior VT, Silva MS, Da-Cunha EVL, Agra MF, SilvaFilho RN, Barbosa-Filho JM, Braz-Filho R 2004. Alkaloids and diterpenes from Croton moritibensis. Int J Pharmacogn 42: 62-67.

Bacchi EM 1996. Controle de qualidade de fitoterápicos. In: Luiz Claudio Di Stasi. Plantas medicinais: arte e ciência. Um guia de estudo interdisciplinar. $1^{\text {st }}$ ed. São Paulo: Editora Unesp. p.169-186.

Barbosa KS, Yoshida M, Scudeller VV 2009. Detection of adulterated copaiba (Copaifera multijuga Hayne) oil-resins by refractive index and thin layer chromatography. Rev Bras Farmacogn 19: 57-60.

Barbosa PR, Fascio M, Martins D, Guedes MLS, Roque NF 2003. Triterpenes of Croton betulaster (Euphorbiaceae). Biochem Syst Ecol 31: 307-308.

Brasil 1973. Presidência da República, Lei no. 5.991, de 17 de dezembro de 1973, Dispõe sobre o Controle Sanitário do Comércio de Drogas, Medicamentos, Insumos Farmacêuticos e Correlatos, e dá outras Providências, Diário Oficial da União.

British Herbal Pharmacopoeia 1996. $4^{\text {th }}$ ed. British Herbal Medicine Association.

Calixto JB 2000. Efficacy, safety, quality control, marketing and regulatory guidelines for herbal medicines (phytotherapeutic agents). Braz J Med Biol Res 33: 179189.

Chan EWC, Lim YY, Chew YL 2007. Antioxidant activity of Camellia sinensis leaves and tea from a lowland plantation in Malaysia. Food Chem 102: 1214-1222.

Cianchino V, Acosta G, Ortega C, Martínez LD, Gomez MR 2008. Analysis of potential adulteration in herbal medicines and dietary supplements for the weight control by capillary electrophoresis. Food Chem 108: 1075-1081.

Danne A, Petereit F, Nahrstedtt A 1994. Flavan-3-ols, prodelphinidins and further polyphenols from Cistus salvifolius. Phytochemistry 37: 533-538.

De Souza KCB, Schapoval EES, Bassani VL 2002. LC determination of flavonoids: separation of quercetin, luteolin and 3-O-methylquercetin in Achyrocline satureioides preparations. J Pharm Biomed Anal 28: 771-777.

Deutsches Arzneibuch 1986. 9. Ausg. Stuttgart: Wissenschaftliche.

Durón RR, Almaguer LC, Garza-Juárez AJ, Cavazos MLS, De-Torres NW 2009. Development and validation of thin-layer chromatographic methods for quality control of herbal products. Acta Chromatogr 21: 203215.

Farias MR 2004. Avaliação da qualidade de matérias-primas vegetais. In: Simões CMO (org.). Farmacognosia: da planta ao medicamento. $5^{\text {th }}$ ed. Porto Alegre: Editora da UFRGS. p. 270-288.

Farmacopeia Brasileira 2002. $4^{\text {th }}$ ed., parte II, fasc.4. São Paulo: Atheneu.

Farmacopeia Brasileira 2003. $4^{\text {th }}$ ed., parte II, fasc.5. São Paulo: Atheneu.

Farmacopeia Brasileira 2010. $5^{\text {th }}$ ed., Parte II, Brasília: Editora da Anvisa.

Farmacopeia Espanhola 2005. $3^{\text {rd }}$ ed., Madri: B.O.E.

Farmacopeia Portuguesa 2002. $7^{\text {th }}$ ed., Lisboa: Infarmed.

Ferenczi-Fodor K, Végh Z, Renger B 2006. Thinlayer chromatography in testing the purity of pharmaceuticals. Trends Anal Chem 25: 778-789.

Głowniak K, Skalicka K, Ludwiczuk A, Jop K 2005. Phenolic compounds in the flowers of Lavatera trimestris $\mathrm{L}$. (Malvaceae). J Planar Chromatogr 18: 264-268.

Harborne JB 1998. Phytochemical Methods: a guide to modern techniques of plant analysis. $3^{\text {rd }}$ ed., London: Chapman and Hall.

Kaiser ER 2005. Methods of detecting and/or reducing systematic errors in quantitative planar chromatography. Part 3. evaluation and calibration errors. J Planar Chromatogr 18: 256-263

Kawashty SA, Gamal ED, Abdalla MF, Saleh NAM 1994. Flavonoids of Plantago species in Egypt. Biochem Syst Ecol 22: 729-733.

Liang Y, Xie P, Chan K 2004. Quality control of herbal medicines. J Chromatogr B 812: 53-70.

Manian R, Anusuya N, Siddhuraju P, Manian S 2008. The antioxidant activity and free radical scavenging potential of two different solvent extracts of Camellia sinensis (L.) O. Kuntz, Ficus bengalensis L. and Ficus racemosa L. Food Chem 107: 1000-1007.

Marques LC, Pieri CD; Roman Júnior WA, Cardoso MLC, Gutierre MAM, Mello JCP 2007. Controle farmacognóstico das raízes de Heteropterys aphrodisiaca O. Mach. 
(Malpighiaceae). Rev Bras Farmacogn 17: 604-615. Mohammad A, Bhawani SA, Sharma S 2010. Analysis of herbal products by thin-layer chromatography: a review. Int J Pharma Bio Sci 1: 1-50.

Müller L, Kasper P 1996. The mutagenic potential of arbutine, a naturally occurring hydroquinone glycoside. Mutat Res 360: 291-292.

Osório AC, Martins JLS 2004. Determinação de cumarina em extrato fluido e tintura de guaco por espectrofotometria derivada de primeira ordem. Rev Bras Ciênc Farm 40: 482-486

Pereira AMS, Câmara FLA, Celeghini RMS, Vilegas JHY, Lanças FM, França SC 2000. Seasonal variation in coumarin content of Mikania glomerata. J Herbs Spices Med Plants 7: 1-10.

Pittet A, Royer D 2002. Rapid, low cost thin-layer chromatographic screening method for the detection of ochratoxin A in green coffee at a control level of 10 $\mu \mathrm{g} / \mathrm{kg}$. J Agric Food Chem 50: 243-247.

Pizzolatti MG, Venson AF, Smania Júnior A, Smania EDFA, Braz-Filho R 2002. Two epimeric flavalignans from Trichilia catigua (Meliaceae) with antimicrobial activity. $J$ Biosci 57: 483-488.

Polydoro M, De Souza KCB, Andrades ME, Da Silva EG, Bonatto F, Heydrich J, Dal-Pizzol F, Schapoval EES, Bassani VL, Moreira JCF 2004. Antioxidant, a pro-oxidant and cytotoxic effects of Achyrocline satureioides extracts. Life Sci 74: 2815-2826.

Poole CF 1999. Planar chromatography at the turn of the century. J Chromatogr A 856: 399-427.

Reich E, Blatter A 2003. HPTLC for the analysis of herbal drugs, herbal drug preparations and herbal medicinal products. In: Sherma J, Fried B, editors. Handbook of Thin-Layer Chromatography 3rd ed., Chapter 18. New York: Dekker.

Resende FO, Rodrigues-Filho E, Luftmann H, Petereit F, Mello JCP 2011. Phenylpropanoid substituted flavan-3-ols from Trichilia catigua and their in vitro antioxidative activity. $J$ Braz Chem Soc, in press.

Sahoo N, Manchikanti P, Dey S 2010. Herbal drugs: standards and regulation. Fitoterapia 81: 462-471.

Schenkel EP, Gosmann G, Athayde ML 2003. Saponinas. In: Simões CMO (org). Farmacognosia: da planta ao medicamento. $5^{\text {th }}$ ed. Florianópolis/Porto Alegre: Editora da UFSC/ Editora da UFRGS, p. 711-740.

Silva AB, Silva T, Franco ES, Rabelo AS, Lima ER, Mota RA, Câmara CAG, Pontes-Filho NT, Lima-Filho JV 2010. Antibacterial activity, chemical composition, and cytotoxicity of leaf's essential oil from Brazilian pepper tree (Schinus terebinthifolius Raddi). Braz J Microbiol 41: 158-163.

Veneziani RCS, Oliveira DCR 1999. Cosntituents of Mikania glomerata Sprengel. Biochem System Ecol 27: 99102.

WHO 2000. General guidelines for methodologies on research and evaluation of traditional medicines. p. 1

Yang CS, Lambert JD 2003. Mechanisms of cancer prevention by tea constituents. J Nutr 133: 3262S-3267S.

Zhang JS, Guan J, Yang FQ, Liu HG, Cheng XJ, Li SP 2008. Qualitative and quantitative analysis of four species of Curcuma rhizomes using twice development thin layer chromatography. J Pharm Biomed Anal 48: 1024-1028.

\section{*Correspondence}

João C. P. de Mello

Programa de Pós-graduação em Ciências Farmacêuticas, Universidade Estadual de Maringá

Av. Colombo, 5790, 87020-900 Maringá-PR, Brazil

mello@uem.br

Tel. + 554430114816

Fax: + 554430115050 